\title{
The Influence of Organizational Culture and Principal Leadership Towards Teacher's Performance
}

\author{
Deslina Prihatini \\ SDN 4 Gelumbang \\ e-mail: prihatin.deslina@yahoo.com \\ Yasir Arafat \\ Universitas PGRI Palembang \\ e-mail: yasirarafat@univpgri-palembang.ac.id \\ Mulyadi \\ Universitas PGRI Palembang \\ e-mail:mulyadi@univpgri-palembang.ac.id \\ Article History: Received on 1 December 2020, Revised on 4 December 2020, \\ Published on 9 January 2021
}

\begin{abstract}
This study determined the effect of organizational culture and principal leadership on teacher performance. This study uses quantitative methods with correlational research. The population of this study was 43 people, namely teachers of public elementary school teachers in Gugus 6, Gelumbang District. The data collection technique used a questionnaire. Data were analyzed using correlation analysis techniques and multiple linear regression. The results of this study indicate that: (1) organizational culture has a significant effect on the performance of Public Elementary School teachers in Gugus 6, Gelumbang District; (2) principal leadership has a significant effect on the performance of Public Elementary School teachers in Cluster 6, Gelumbang district, and (3) organizational culture and principal leadership simultaneously have a significant effect on the performance of public elementary school teachers in Gugus 6, Gelumbang District.
\end{abstract}

Keywords: Organizational Culture, Principal Leadership, Teacher's Performance

\section{A. Introduction}

The role of teachers in improving the quality of education is very important, because teachers are directly involved in teaching and educating students. Professional teachers have social responsibility manifested through teacher competence from the social environment and have effective interactive skills. According to Law No. 14 of 2005 teachers are professional educators with the main task of educating, teaching, guiding, directing, assessing, training and evaluating students in early childhood education through formal education, basic education, and secondary education. Human resources must be empowered in information technology to become professional teachers (Rahmadoni, 2018). All educational institutions in Indonesia have a duty and responsibility to build a generation that is potential and able to compete in the world market (Tobari et al, 2018). Education has a role and strategic function in order to produce the children's creativity (Lian et al, 2018). Teachers must find learning methods so that students participate actively in the learning process. 
National primary school teacher performance according to the Center for Data and Statistics on Education and Culture (Kemendikbud, 2016) of 74.83 is in the low category. The performance of elementary school teachers in the province of South Sumatra was 72.53 in the poor category. To get an overview of the performance of teachers at the Gelumbang District Public Elementary Schools, the researchers conducted preliminary observations with short oral interviews with 20 teachers about teacher performance. Based on the results of the interview, it was found that the performance of SD Negeri teachers in Gelumbang District was still not good enough. As many as $50 \%$ of teachers stated that they were not optimal in compiling teaching plans. Meanwhile, teachers who had difficulty assessing learning outcomes, especially $\mathrm{K} 13$, were $80 \%$. Meanwhile, $35 \%$ of teachers who do not take the initiative to develop positive attitudes, $12 \%$ of teachers who do not innovate in developing learning and $25 \%$ of teachers lack discipline in carrying out their assignments.

Good teacher performance is obtained from the role of the principal's leadership as a trigger for increasing competence, motivation, and teacher performance. Teacher performance will be optimal if it is integrated with school components, whether it is the principal or students (Alhusaini et al, 2020). Principal leadership behavior is a work process that can help improve the quality of teachers to achieve school goals. The role of the principal as a leader with his leadership style must be able to influence other people or subordinates must have good emotional intelligence (Asvio et al, 2019). Pidarta (2004) states that there are several factors that can affect teacher performance in carrying out their duties, namely the leadership of the principal, work facilities, expectations, and trust in school personnel. Leadership is a way to direct and influence subordinates for certain goals (Rahmadoni, 2018). The principal must be able to practice innovations, be able to direct all members and the school.

The principal's ability to lead can be seen from his success in improving quality in schools. Principals who are able to lead will certainly try to improve the quality of their schools through collaboration with teachers, staff, committees and all stakeholders. This is in line with Austin's research in Imron (2015) which states that the difference between high and low achieving educational institutions lies in the influence of their leaders. The principal faces greater challenges than the past in carrying out the duties and functions he plays on a daily basis (Komalasari et al, 2020).

According to Schein in Samsuddin (2018) states that organizational culture and leadership are interrelated with each other. An organization needs a leader who has the ability and influence to direct his subordinates towards achieving organizational goals. Yulizar (2020) states that there is a significant influence between organizational culture and principal leadership on teacher performance at SMA Negeri Tanjung Raja District.

Many factors affect teacher performance, both external and internal factors (Maryati et al, 2020). According to Safitri (2019), the performance of professional teachers is the level of success in carrying out their duties and responsibilities in achieving the goals and standards that have been set. The Regulation of the Minister of National Education Number 35 of 2010 states that teacher performance is an assessment of the process and work achieved by the teacher in carrying out their duties. A person's performance can be influenced by several supporting factors. According to Pidarta (2004) there are several factors that can affect teacher performance in carrying out their duties, namely: Principal leadership, work facilities, expectations, and trust in school personnel. Teachers must find learning methods so that students participate actively in the learning process. 
Volume 1 (3) 2020

E-ISSN: 2723-6919 P-ISSN:2746-0827

Among the many factors that affect teacher performance, organizational culture and principal leadership are factors that greatly affect teacher performance, because the work situation is conducive, orderly, orderly and comfortable and the principal's leadership can influence teachers in a better direction and provide examples of attitudes positive certainly can improve teacher performance.

School as a form of organization has its own culture which forms the features of a complete and distinctive system and is related to the culture of the surrounding community. The organizational culture at school is formed from the results of the meeting between the values held by the principal as a leader and the values shared by teachers, employees, students and other school members.

According to Tobari (2015) organizational culture that is easy to adapt to changing times (adaptive) is what can improve performance. Organizational culture according to Robbins in Wibowo (2016) is a general perception that guides organizational members, a system of shared meaning. Furthermore, Wibowo (2016) states that the function of organizational culture is: 1) showing identity; 2) clarifying standards of behavior; 3) shows clear role boundaries; 4) build a sound and reasonable mind; 5) shows collective commitment; 6) clarify standards of behavior. The leadership role of the principal is as key in shaping the school culture so that a positive culture is formed for school improvement and teaching and is able to establish harmonious relationships with internal and external school groups. Work culture has long been known by humans, baut it has not been realized that work success is rooted in the values that are owned and behaviors thar become habits (Abdullah, 2020). Afifudin (2015) states that the leadership role has two specifications, namely; 1) as top management, namely conducting planning, organizing, staffing, directing, commanding, controlling, and so on; 2) administrative function, namely compiling administrative policies.

Previous studies used in this study for consideration and reference are as follows. Handayani, et al. (2015) can conclude from the results of their research that there is a significant influence on the principal's participatory leadership style, teacher work motivation, and school organizational culture together on teacher performance. Handayani's research has a similarity with the author's research, namely examining school leadership and organizational culture on teacher performance. While the difference is that Handayani's research has one more variable, namely about work motivation, while the research currently being conducted does not use it. Another difference was that the research was conducted on teachers at SMAN in Wonosobo Regency, while research at SDN in Gelumbang District.

Further research by Darmawan (2016) from the results of his research can be concluded that the better the principal managerial ability and organizational culture, the better the teacher's performance. The results of research from Samsuddin (2018) on employee performance at the Education Office in South Sumatra Province are that there is a significant positive effect of leadership style, organizational culture and organizational commitment to employee performance.

\section{B. Methods}

The research site was carried out in Cluster 6, Gelumbang District, consisting of 4 State Elementary Schools, namely SDN 3 Gelumbang, SDN 4 Gelumbang, SDN 11 Gelumbang and SDN 22 Gelumbang. The study was conducted from November 2019 to March 2020. The 
Volume 1 (3) 2020

E-ISSN: 2723-6919 P-ISSN:2746-0827

population was 43 teachers. The sampling technique in this study used a census technique, meaning that all members of the population were taken to be the entire sample Arikunto (2010).

This study uses a quantitative correlational method to explain the associative relationship between the independent variable and the dependent variable. According to Suryabrata (2015), correlational research aims to determine the extent to which the variation of a factor is related to other factors based on the correlation coefficient. The data collection technique consisted of a documentation study and a questionnaire. The data obtained were analyzed with simple linear regression analysis techniques and multiple linear regression with the help of SPSS version 22.

The instrument to be used needs to be tested in order to obtain valid and reliable instruments. Respondents who will fill out the instrument questionnaire totaling 30 teachers are made to teachers who are not included in the study population. Furthermore, to obtain valid and reliable statement items, validity and reliability were tested. Testing the validity of the instrument can be determined through calculations using the Product Moment Correlation formula to the values between variable $\mathrm{X}$ and variable $\mathrm{Y}$.

\section{Results and Discussion}

1. Testing the partial hypothesis of organizational culture variables $\left(\mathrm{X}_{1}\right)$ on Teacher Performance (Y)

Table 1. Results of the coefficient of simple linear regression analysis partially organizational culture variables $\left(X_{1}\right)$ on Teacher Performance $(Y)$

Coefficients $^{\mathbf{a}}$

\begin{tabular}{|c|c|c|c|c|c|c|}
\hline \multirow{2}{*}{\multicolumn{2}{|c|}{ Model }} & \multicolumn{2}{|c|}{$\begin{array}{c}\text { Unstandardized } \\
\text { Coefficients }\end{array}$} & \multirow{2}{*}{$\begin{array}{c}\text { Standardized } \\
\text { Coefficients } \\
\text { Beta }\end{array}$} & \multirow[t]{2}{*}{$\mathrm{t}$} & \multirow[t]{2}{*}{ Sig. } \\
\hline & & B & Std. Error & & & \\
\hline & (Constant) & 23.741 & 9.244 & & 2.568 & .014 \\
\hline & $\begin{array}{l}\text { Organizational } \\
\text { Culture }\left(\mathrm{X}_{1}\right)\end{array}$ & .807 & .092 & .807 & 8.765 & .000 \\
\hline
\end{tabular}

a. Dependent Variable: Teacher Performance (Y)

Table 2. The results of the analysis of the coefficient of determination of organizational culture variables $\left(\mathrm{X}_{1}\right)$ on Teacher Performance $(\mathrm{Y})$

Model Summary

\begin{tabular}{lrrrrr}
\hline Model & $\mathrm{R}$ & R Square & Adjusted R Square & \multicolumn{2}{c}{ Std. Error of the Estimate } \\
\hline 1 & $.807^{\mathrm{a}}$ & .652 & .644 & 4.574 \\
\hline
\end{tabular}

a. Predictors: (Constant), Organizational Culture $\left(\mathrm{X}_{1}\right)$

The results of the study show that organizational culture has a significant effect on teacher performance. These results support the first hypothesis proposed where organizational culture has a significant effect on teacher performance. The influence of organizational culture variables on teacher performance is $65.2 \%$, meaning that organizational culture has a large 
Volume 1 (3) 2020

E-ISSN: 2723-6919 P-ISSN:2746-0827

enough influence on teacher performance. From the table above, it can be seen that the significance value of the organizational culture Linearity is $0.000<0.05$ and the significance value of Deviation from Linearity of $0.684>0.05$ means that there is a linear relationship between organizational culture and teacher performance.

Based on the table above, it can be seen that the $\mathrm{R}$ value for organizational culture of 0.807 means the relationship between organizational culture $\left(\mathrm{X}_{1}\right)$ and teacher performance $(\mathrm{Y})$ indicates a very strong relationship category because it is in the range $0.80-1,000$.

The influence of the organizational culture variable $\left(\mathrm{X}_{1}\right)$ on teacher performance $(\mathrm{Y})$ can be seen from the coefficient of determination $\left(\mathrm{R}^{2}\right)$. Based on the Model Summary table output above, the R2 value is 0.652 or $65.2 \%$. The influence of organizational culture variables on teacher performance is $65.2 \%$, the rest is influenced by other factors.

The results of this study are in line with the research of Febriantina, et al. (2018) which states that there is a positive and significant influence between organizational culture and teacher performance at SMK Negeri 40 Jakarta. The results of Rahayu's research (2014) in her research entitled "The relationship between organizational culture and teacher performance in private elementary schools in Koto Tengah Padang sub-district" states that organizational culture is at the moderate level of achievement and teacher performance is at a high level of achievement. Samsuddin (2018) states that a strong organizational culture will create positive achievements for its members, thereby increasing performance.

Based on the results of existing data in the field and partial data analysis, organizational culture variables have a positive and significant effect on the dependent variable, namely teacher performance.

2. Testing the partial hypothesis of principal leadership variables $\left(\mathrm{X}_{2}\right)$ on Teacher Performance (Y)

Table 3. Results of the coefficient of simple linear regression analysis partially of principal leadership variables $\left(\mathbf{X}_{2}\right)$ on Teacher Performance $(\mathbf{Y})$

\section{Coefficients $^{\mathrm{a}}$}

\begin{tabular}{|c|c|c|c|c|c|c|}
\hline \multirow[t]{2}{*}{ Model } & \multicolumn{2}{|c|}{$\begin{array}{l}\text { Unstandardized } \\
\text { Coefficients }\end{array}$} & \multicolumn{2}{|c|}{$\begin{array}{c}\text { Standardized } \\
\text { Coefficients }\end{array}$} & \multirow[t]{2}{*}{$\mathrm{T}$} & \multirow[t]{2}{*}{ Sig. } \\
\hline & B & Std. Error & Beta & & & \\
\hline 1 (Constant) & 19.067 & 10.240 & & & 1.862 & .070 \\
\hline $\begin{array}{l}\text { Principal } \\
\text { Leadership }\left(\mathrm{X}_{2}\right)\end{array}$ & .842 & .101 & & .794 & 8.367 & .000 \\
\hline
\end{tabular}

a. Dependent Variable: Teacher Performance (Y)

Table 4. The results of the analysis of the coefficient of determination of principal leadership variables $\left(\mathbf{X}_{2}\right)$ on Teacher Performance $(\mathbf{Y})$

Model Summary

\begin{tabular}{lcrrr}
\hline Model & R & R Square & Adjusted R Square & Std. Error of the Estimate \\
\hline 1 & $.794^{\mathrm{a}}$ & .631 & .622 & 4.712 \\
\hline
\end{tabular}

a. Predictors: (Constant), Principal Leadership $\left(\mathrm{X}_{2}\right)$ 
Based on the table above, it can be seen that the $\mathrm{R}$ value for school principal leadership is 0.794, which means that the relationship between principal leadership (X2) and teacher performance (Y) indicates a strong relationship category because it is in the range 0.60 0.799. Meanwhile, the influence of the principal's leadership variable (X2) on teacher performance (Y) can be seen from the coefficient of determination (R2). Based on the Model Summary table output above, the R2 value is 0.631 or $63.1 \%$. The influence of the principal's leadership variable on teacher performance is $63.1 \%$, the rest is influenced by other factors.

In the table above, it is known that the $t$ value is 8.367 with a significant level of 0.000 . This value is the $t$ value, then compared with the $t$ table value. The results obtained for $t$ table is 2.019. If tcount $>$ ttable and a significance value $<0.005$, then $\mathrm{H} 01$ is rejected and $\mathrm{Ha} 1$ is accepted. The $t$ value of 8.367> 2.019 and the significance value of $0.000<0.005$ means that $\mathrm{H} 02$ is rejected and $\mathrm{Ha} 2$ is accepted. It can be concluded that the principal's leadership has a significant effect on teacher performance.

From the above equation it can be interpreted that a constant value of 19.067 states that when the principal's leadership value is zero, the teacher's performance value is 19.067. While the principal leadership value $\left(\mathrm{X}_{2}\right)$ of 0.842 states that the increase in one unit variable.

The research results show that the principal's leadership has a significant effect on teacher performance. These results support the second hypothesis proposed where the principal's leadership has a significant effect on teacher performance. The influence of the principal's leadership variable on teacher performance is $63.1 \%$, the rest is influenced by other factors.

Kasidah (2017) argues that the principal's policy program can improve teacher performance both directly and indirectly.

Based on the results of data in the field and partial data analysis, the principal leadership variable has a positive and significant effect on the dependent variable, namely teacher performance.

\section{Simultaneous Hypothesis Testing for Variables $X_{1}$ and $X_{2}$ to $Y$}

Tabel 5. Hypothesis

\begin{tabular}{|c|c|c|c|c|c|c|}
\hline \multicolumn{7}{|c|}{ ANOVA $^{a}$} \\
\hline & Model & $\begin{array}{c}\text { Sum of } \\
\text { Squares }\end{array}$ & Df & $\begin{array}{l}\text { Mean } \\
\text { Square }\end{array}$ & $\mathrm{F}$ & Sig. \\
\hline \multirow[t]{3}{*}{1} & Regression & 1617.815 & 2 & 808.907 & 38.206 & $.000^{\mathrm{b}}$ \\
\hline & Residual & 846.883 & 40 & 21.172 & & \\
\hline & Total & 2464.698 & 42 & & & \\
\hline \multicolumn{7}{|c|}{ a. Dependent Variable: $Y$} \\
\hline \multicolumn{7}{|c|}{ b. Predictors: (Constant), $\mathrm{X}_{2}, \mathrm{X}_{1}$} \\
\hline
\end{tabular}


Table 6. Result of Simultaneous Variable Linear Regression Coefficient of organizational culture variables $\left(X_{1}\right)$ and principal leadership variables $\left(X_{2}\right)$ on Teacher Performance (Y)

Coefficients $^{\mathbf{a}}$

\begin{tabular}{|c|c|c|c|c|c|}
\hline \multirow[t]{2}{*}{ Model } & \multicolumn{2}{|c|}{$\begin{array}{l}\text { Unstandardized } \\
\text { Coefficients }\end{array}$} & \multirow{2}{*}{$\begin{array}{c}\text { Standardized } \\
\text { Coefficients } \\
\text { Beta } \\
\end{array}$} & \multirow[t]{2}{*}{$\mathrm{T}$} & \multirow[t]{2}{*}{ Sig. } \\
\hline & $\mathrm{B}$ & Std. Error & & & \\
\hline 1 (Constant) & 20.998 & 10.062 & & 2.087 & .043 \\
\hline $\begin{array}{l}\text { Organizational } \\
\text { Culture }\left(\mathrm{X}_{1}\right)\end{array}$ & .578 & .334 & .578 & 1.731 & .091 \\
\hline $\begin{array}{l}\text { Principal } \\
\text { Leadership }\left(\mathrm{X}_{2}\right)\end{array}$ & .253 & .354 & .239 & .714 & .479 \\
\hline
\end{tabular}

a. Dependent Variable: Teacher Performance (Y)

Table 7. Results of the Analysis of the Simultaneous Determination of Variables $X_{1}$ and $\mathbf{X}_{2}$ against $\mathbf{Y}$

Model Summary Model R R Square Adjusted R Square Std. Error of the Estimate

\begin{tabular}{lllll}
1 & $.810^{\mathrm{a}}$ & .656 & .639 & 4.601 \\
\hline
\end{tabular}

From the table above, it can be seen that the calculated $\mathrm{F}$ value $=38.206>3.23$. The value of $\mathrm{F}$ table can be seen in the statistical table with a significance of 0.05 in the degrees of freedom df $1=\mathrm{k}-1$ or $3-1=2(\mathrm{k}=$ number of variables $)$ and df $2=\mathrm{n}-\mathrm{k}$ or $43-3=40(\mathrm{n}=$ number of respondents) (Prayitno, 2010). The results obtained for F table $(0.05,2.40)$ of 3.23. The significance value of $0.000<0.005$ and the value of Fcount $>$ the value of Ftable (38.2016> 3.23), it can be concluded that the organizational culture and the performance of school principals have a significant effect on teacher performance together.

From the above equation it can be interpreted that a constant value of 20.998 states that when the value of organizational culture and principal leadership is zero, teacher performance is 20.998. Meanwhile, the value of organizational culture $\left(\mathrm{X}_{1}\right)$ of 0.578 states that an increase in one unit value for the organizational culture variable can increase teacher performance by 0.578 units with the assumption that other variables are constant. Likewise, the principal leadership value $\left(\mathrm{X}_{2}\right)$ of 0.253 states that an increase in one unit of the principal's leadership value is 0.253 units, assuming other variables are constant.

Based on the table above, it can be seen that the $\mathrm{R}$ value for organizational culture and principal leadership of 0.810 means the relationship between organizational culture $\left(\mathrm{X}_{1}\right)$ and principal leadership $\left(\mathrm{X}_{2}\right)$ on teacher performance $(\mathrm{Y})$ indicates a very strong relationship category because it is in range $0,80-.1000$.

Meanwhile, the influence of the variable organizational culture $\left(\mathrm{X}_{1}\right)$ and principal leadership (X2) together on teacher performance (Y) can be seen from the coefficient of determination (R2). Based on the Model Summary table output above, the R2 value is 0.656 or $65.6 \%$. The influence of organizational culture variables and principal leadership on teacher performance 
Volume 1 (3) 2020

E-ISSN: 2723-6919 P-ISSN:2746-0827

was $65.6 \%$, the remaining $34.4 \%$ was influenced by other factors which were not analyzed in this study.

Based on the results of the simultaneous significance test, the F calculation results are 38.206 and the probability ( $\mathrm{Sig}$ ) 0.000 so that it can be concluded that there is an influence between organizational culture and principal leadership together on the performance of teachers in SDN 3, SDN 4, SDN 11 and SDN 22 Gelumbang in Cluster 6 Gelumbang District.

\section{Conclusion}

Based on the results obtained, the organizational culture significance value is $0,000<0.05$, then $\mathrm{Ha}$ is accepted, the principal leadership significance value is $0,000<0.05$, then $\mathrm{Ha}$ is accepted and the significance value of organizational culture and principal leadership simultaneously is $0,000<0.05$, then Ha be accepted. Based on the results of research on three variables, namely organizational culture (X1), principal leadership (X2) and teacher performance (Y) of Public Elementary Schools in Cluster 6, Gelumbang District, that: first, Organizational Culture has a significant effect on the performance of Public Elementary School teachers in Cluster 6. Gelumbang sub-district, the two principal leadership have a significant effect on the performance of public elementary school teachers in cluster 6 of Gelumbang sub-district, the three organizational culture and principal leadership simultaneously have a significant effect on the performance of public elementary school teachers in cluster 6 of Gelumbang district.

\section{E. Acknowledgement}

Chancellor of the PGRI Palembang University, the Director of the PGRI Palembang University Postgraduate Program and the PGRI Palembang University Education Management Study Program for supporting us to do this extraordinary thing. This project is independently funded. We would also like to thank our friends in Education Management who helped us a lot in completing this project in a limited time frame.

\section{References}

Abdullah, A. (2020). Relationship the Work Culture and Training Programs Within Performance. International Journal of Progressive Sciences and Technologies (IJPSAT), 20(1).

Afifudin. (2015). Kepemimpinan Pendidikan [Educational Leadership]. Bandung: Pustaka Setia.

Alhusaini, A., Kristiawan, M.., \& Eddy, S. (2020). Pengaruh Motivasi Kerja dan Disiplin Kerja terhadap Kinerja Guru. Jurnal Pendidikan Tambusai, 4(3), 2166-2172. Retrieved from https://jptam.org/index.php/jptam/article/view/693Mangkunegara. (2011. Evaluasi Kinerja Sumber Daya Manusia. Bandung: Refika Aditama.

Arikunto, S. (2010). Prosedur Penelitian: Suatu Pendekatan Praktik [Research Procedure: A Practice Approach]. Jakarta: Rineka Cipta. 
Volume 1 (3) 2020

E-ISSN: 2723-6919 P-ISSN:2746-0827

Asvio, N., Yamin, M., \& Risnita. (2019). Influence of Leadership Style, Emotional Intelligence and Job Satisfaction toward Organizational Commitment (Survey at SMA Muhammadiyah South Sumatera). International Journal of Scientific \& Technology Research 8 (8).

Darmawan, D. (2016). Hubungan antara Kemampuan Manajerial Kepala Sekolah dan Budaya Organisasi dengan Kinerja Guru Satuan Unit Pendidikan di Perguruan Darur Ma'arif, Cipete Selatan [Relationship between Principal Managerial Ability and Organizational Culture with Teacher Performance in Education Unit Units at Darur Ma'arif College, Cipete Selatan]. Jurnal Sekretari Vol. 3, No. 2.

Febriantina, S., Lutfiani, F. N., \& Zein, N. (2018). Pengaruh Budaya Organisasi terhadap Kinerja Guru di SMK Negeri 40 Jakarta [The Influence of Organizational Culture on Teacher Performance at SMK Negeri 40 Jakarta]. Jurnal Tadbir Muwahhid 2(2) 120131.

Handayani, T. dkk (2015) Pengaruh Kepemimpinan Kepala Sekolah, Motivasi Guru dan Budaya Organisasi Terhadap Kinerja Guru SMA Negeri Wonosoba [The Influence of Principal Leadership, Teacher Motivation and Organizational Culture on Teacher Performance at SMA Negeri Wonosoba]. Jurnal Akuntabilitas Manajemen Pendidikan Volume 3, No 2.

Imron, A. (2015). Proses Manajemen Tingkat Satuan Pendidikan [Educational Unit Level Management Process]. Jakarta: Bumi Aksara.

Kasidah. (2017). Kepemimpinan Kepala Sekolah dalam Meningkatkan Kinerja Guru pada Sekolah Dasar Luar Biasa Negeri Banda Aceh [Leadership of the Principal in Improving Teacher Performance at the Banda Aceh Special Primary School]. Jurnal Magister Administrasi Pendidikan Pascasarjana Universitas Syiah Kuala.

Kemendikbud. (2016). Sumber Daya Manusia Pendidikan Dasar Dan Menengah [Primary and Secondary Education Human Resources]. Jakarta: Pusat Data dan Statistik pendidikan Dan Kebudayaan http://publikasi.data.kemendikbud.go.id/index analisis.php?thn=2016.

Komalasari, K., Arafat, Y., \& Mulyadi, M. (2020). Principal's Management Competencies in Improving the Quality of Education. Journal of Social Work and Science Education, 1(2), 181-193. Retrieved from https://ejournal.karinosseff.org/index.php/jswse/article/view/47

Lian, B., Kristiawan, M., \& Fitriya, R. (2018). Giving Creativity Room to Students through the Friendly School's Program. International Journal of Scientific \& Technology Research, 7(7).

Maryati, E., Fitria, H., \& Rohana, R. (2020). The Influence of Principal's Leadership Style and Organizational Culture on Teacher's Performance. Journal of Social Work and Science Education, 1(2), 127-139. Retrieved from https://ejournal.karinosseff.org/index.php/jswse/article/view/38 
Pidarta, M. (2004). Manajemen Pendidikan Indonesia [Indonesian Education Management]. Jakarta: Rineka Cipta.

Prayitno, D. (2010). Teknik Mudah dan Cepat Melakukan Analisis Data Penelitian dengan SPSS [Easy and Fast Techniques to Perform Research Data Analysis with SPSS]. Yogyakarta: Penerbit Gava Media.

Rahayu, F. (2014). Hubungan Budaya Organisasi dengan Kinerja Guru di Sekolah Dasar Swasta Kecamatan Koto Tengah Padang [The Relationship between Organizational Culture and Teacher Performance in Private Primary Schools, Koto Tengah District, Padang]. Jurnal Administrasi Pendidikan Bahana Manajemen Pendidikan Vol.2, No.1.

Rahmadoni, J. (2018). Isu Global Manajemen Pembiayaan Pendidikan di SD Indonesian Creative School Pekanbaru [Global Issues of Education Financing Management at SD Indonesian Creative School Pekanbaru]. Jurnal Manajemen, Kepemimpinan dan Supervisi Pendidikan 3(2).

Rahmadoni, J. (2018). Perancangan Simulasi Pembelajaran Kriptografi Klasik Menggunakan Metode Web Based Learning [Designing Classical Cryptography Learning Simulation Using Web Based Learning Method]. INTECOMS: Journal of Information Technology and Computer Science, 1(1), 34-43. https://doi.org/https://doi.org/10.31539/intecoms.v1i1.160

Safitri, D. (2019). Menjadi Guru Profesional [Become a Professional Teacher]. Riau: PT Indragiri.Dot.com.

Suryabrata, S. (2015). Metodologi Penelitian [Research methodology]. Jakarta: Rajawali Press.

Tobari. (2015). Membangun Budaya Organisasi pada Instansi Pemerintahan [Building Organizational Culture in Government Agencies]. Yogyakarta: Deepublish.

Tobari., Kristiawan, M. \& Asvio, N. (2018). The Strategy of Headmaster on Upgrading Educational Quality in Asean Economic Community (AEC) Era. International Journal of Scientific \& Technology Research 7 (4).

Wibowo. (2016). Budaya Organisasi: Sebuah Kebutuhan untuk Meningkatkan Kinerja Jangka Panjang [Organizational Culture: A Need to Improve Long-Term Performance]. Jakarta: Rajawali Press.

Yulizar., Arafat, Y., \& Rohana. (2020). Pengaruh Budaya Organisasi dan Kepemimpinan Kepala Sekolah terhadap Kinerja Guru di SMA Negeri Tanjung Raja [The Influence of Organizational Culture and Principal Leadership on Teacher Performance at SMA Negeri Tanjung Raja]. Jurnal Intelektualita: Keislaman, Sosial, dan Sains Vol.9, No.1. 